\title{
Keabsahan Akta Yang Dibuat Oleh Notaris Dengan Digital Signature
}

\author{
Ni Nengah Nuri Sasmita ${ }^{1}$ I Dewa Ayu Dwi Mayasari²
}

1Fakultas Hukum Universitas Udayana, E-mail: Nsasmita72@gmail.com

2Fakultas Hukum Universitas Udayana, E-mail: dewaayudwimayasari@gmail.com

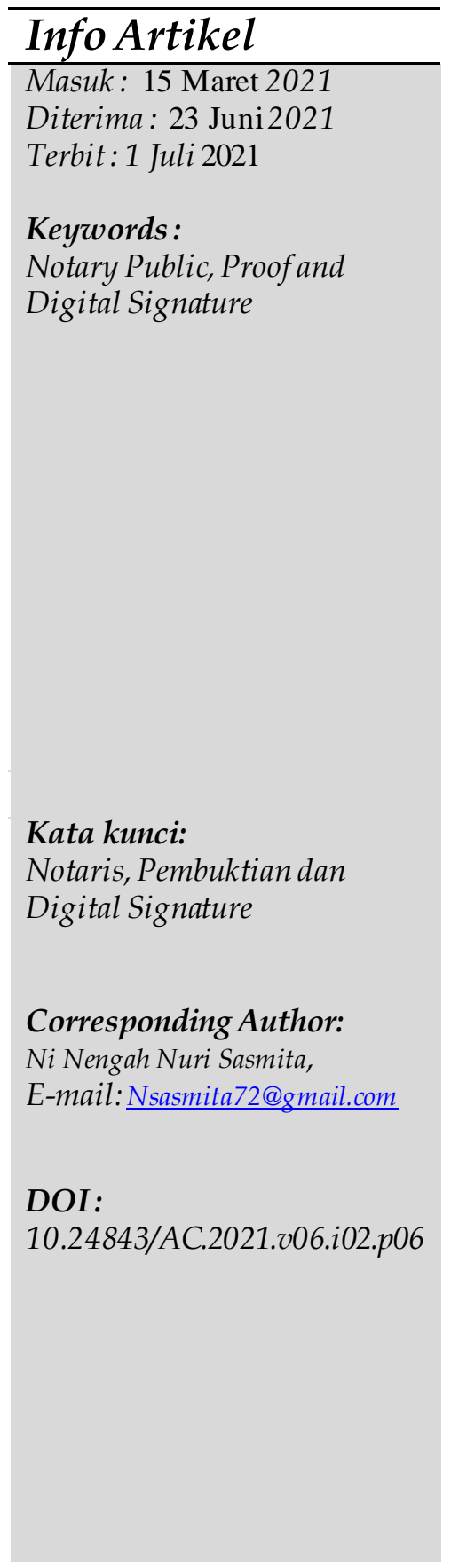

\begin{abstract}
The purpose of this paper is to determine the procedure for making deeds with a digital signature and the authenticity of notary deeds related to the relevance of using a digital signature. The research method he uses is normative legal research method with statutory approaches and legal concepts. The results of this study indicate that the process of making a notary deed electronically is almost the same as the process of making a conventional deed. After a draft deed is ready, a process of reading the contents of the deed is carried out which will be signed by the parties. The interested parties then agree to the contents of the deed, then the notary then notifies all parties to then sign the deed with a digital signature. Then the notary verifies all the signs. As evidence, where in the letter or deed there is a digital signature, in Indonesia the power of which can be decomposed into an authentic deed or underhanded deed and entered into documentary evidence. Authentic deed if the digital signature has been verified. Enter the Deed under hand if the digital signature has not been verified.
\end{abstract}

\footnotetext{
Abstrak

Tujuan penulisan ini yaitu untuk mengetahuiprosedur daripada pembuatan duatu akta dengan penggunaan digital signature serta keotentikan akta notaris terkait relevansi daripada penggunaan digital signature. Metode penelitian yang digunakannyaadalah metode penelitian hukum normatifdengan jenis pendekatan perundang-undangan dan juga konsep hukum. Hasil dari penelitian ini menunjukkan bahwa pembuatan akta notaris dengan secara elektronik itu hampir mirip prosesnya dengan proses pembuatannya akta secara konvensional. Setelah suatu draft aktanya siap, dilakukanlah proses pembacaan isi aktanya yang nantinya akan di tandatangani oleh para pihak. Para pihak yang berkepentingan itu lalu menyetujui isi-isi dari aktanya, maka selanjutnya notaris lalu memberitahu semua pihak-pihak untuk selanjutnya menandatangani akta dengan digital signature. Lalu notaris memverifikasikan semua tanda tanga tersebut. Sebagai alat bukti, maka dimana dalam surat atau aktanya yang terdapat digital signature tersebut, di Indonesia yang kekuatannya dapat bisa diuraikan jadi akta otentik atau akta dibawah tangan dan masuk ke dalam alat bukti surat. Akta otentik apabila digital signaturnya telah terverifikasi.
} 
Masuk ke dalam Akta dibawah tanganjika digital signaturenya belum terverifikasi.

\section{Pendahuluan}

Perkembangan suatu teknologi informasi yang tentunya sangatlah cepat tentu mempengaruhi pada profesi hukum yang yaitu profesi notaris. Peluang juga tantangan untuk Notaris di era globalisasi sekarang ini ialah hadirnya tuntutan agar Notaris tak saja hanya bekerja dengan secara manual tapi juga harus mampu dalam memanfaatkan informasi-informasi berbasis teknologi. ${ }^{1}$ Jabatan notaris ini erat kaitannya dengan pelayanan kepada masyarakat, khususnya dalam melayani dunia usaha. Bagi dunia usaha selain membutuhkan jaminan kepastian hukum, juga dibutuhkan kecepatan/ keluwesan. Kecepatan perkembangan dunia usaha ini seringkali tidak berjalan beriringan dengan norma hukum yang kaku yang lebih menekankan pada aspek kepastian hukum. ${ }^{2}$ Tugas-tugas dari notaris diantaranya itu ialah membuat suatu akta yang otentik. Akta yang dimaksud itu, yakni suatu akta otentik itu dibuatnya dihadapannya notaris yang sesuai dengan prosedur. Berkenaan dengan dibuatnya akta dan hal itu merupakan suatu kewenangan-kewenangannya dari Notaris yang telah diatur dalam Pasal 15 Undang-Undang Nomor 2 Tahun 2014 tentang Perubahan Atas Undang-Undang Nomor 30 Tahun 2004 tentang Jabatan Notaris (yang selanjutnya disebut UUJN). ${ }^{3}$

Notaris memiliki suatu peranan yang sangat penting dikarenakan menyangkut mengenai kebutuhan untuk adanya suatu alat bukti yang tertulis pada bidang hukum perdata, dan sehingga dari hal itu merupakan suatu kekuatannya yang autentik yang tentunya harus mentaati peraturan pada bidangnya notariat, yakni UUJN. Kewenangan dari Notaris dalam UUJN diatur dalam ketentuan Pasal 15 ayat (1), (2), dan (3) UUJN. Pasal 15 ayat (1): “(1) Notaris berwenang membuat akta otentik mengenai semua perbuatan, perjanjian, dan ketetapan yang diharuskan oleh peraturan perundang-undangan dan/atau yang dikehendaki oleh yang berkepentingan untuk dinyatakan dalam akta otentik, menjamin kepastian tanggal pembuatan akta, menyimpan akta, memberikan grosse, salinan dan kutipan akta, semuanya itu sepanjang pembuatan akta-akta itu tidak juga ditugaskan atau dikecualikan kepada pejabat lain atau orang lain yang ditetapkan oleh undang-undang." Pasal 15 ayat (2): "Selain kewenangan sebagaimana dimaksud pada ayat (1) Notaris berwenang pula : a. mengesahkan tandatangan dan menetapkan kepastian tanggal surat dibawahtangan dengan mendaftar dalam buku khusus; b. membukukan surat-surat di bawah tangan dengan mendaftar dalam buku khusus; c. membuat kopi dari asli surat-surat dibawahtangan berupa salinan yang memuat uraian sebagaimana ditulis dan

${ }^{1}$ Putri, C. C., \& Budiono, A. R. (2019). Konseptualisasi Dan Peluang Cvber Notary Dalam Hukum. Jurnal Ilmiah Pendidikan Pancasila dan Kewarganegaraan,4(1), 29-36. h.29, DOI: http://dx.doi.org/10.17977/um019v4i1p29-36

2 Alwaidi, M. F. (2020). Urgensi Pengaturan Cyber Notary Dalam Mendukung Kemudahan Berusaha Di Indonesia. Jurnal Rechts Vinding: Media Pembinaan Hukum Nasional, 9(2), 257. h.258. DOI: http:/ /dx.doi.org/10.33331/rechtsvinding.v9i2.422

3 Abdullah, N. (2017). Kedudukan Dan Kewenangan Notaris Dalam Membuat Akta Otentik. Jurnal Akta, 4(4), 655-664. h.659, DOI : http://dx.doi.org/10.30659/akta.v4i4.2508 
digambarkan dalam surat yang bersangkutan; d. melakukan pengesahan kecocokan fotokopi dengan surat aslinya; e. memberikan penyuluhan hukum sehubungan dengan pembuatan akta; $f$. membuat akta yang berkaitan dengan pertanahan;atau g. membuat akta risalah lelang." Pasal 15 ayat (3): "Selain kewenangan sebagaimana dimaksud pada ayat (1) dan ayat (2), Notaris mempunyai kewenangan lain yang diatur dalam peraturan perundang-undangan." 4

Khusus dari kewenangannya bagi notaris untuk mensertifikasikan transaksi elektronik diatur pada ketentuan Pasal 15 ayat (3) UUJN. Hal ini diatur pada Penjelasan Pasal 15 ayat (3) UUJN yang terkait Cyber Notary. Pasal ini dalam melakukan sertifikasi dari transaksi elektronik (Cyber Notary) dapat dijadikan payung hukum. ${ }^{5}$ Notaris itu mempunyai kewenangan yang untuk dalam hal mensertifikasikan transaksinya yang dilaksanakan melalui madia elektronik dengan menggunakan suat digital signature dalam konsep tersebut. Jadi, terdapat system yang diakuinya itu sebagai hal sarana untuk pensertifikasian 6 Pengaturan pada Pasal 1 angka 12 Undang-Undang Nomor 19 Tahun 2016 tentang Perubahan Atas Undang-Undang Nomor 11 Tahun 2008 tentang Informasi dan Transaksi Elektronik (selanjutnya disebut UU ITE) itu mengatur bahwa: "tanda tangan elektronik adalah tanda tangan yang terdirinya atau terkait dengan suatu informasi elektronik lainnya yang juga digunakan sebagai suatu alat verifikasi dan autentifikasi." Sedangkan Pasal 1 angka 13 UU ITE: "penanda tangan merupakan subjek hukum yang berkaitan dengan digital signature."

Transaksi melalui elektronik terdapat untuk menggunakan suatu digital signature dikarenakan hal itu dianggapnya tentu memberikan suatu efisiensi dalam proses transaksinya. Suatu akibat dari suatu kemajuannya teknologi informasi khususnya yaitu internet ialah semakin meningkatnya jumlah transaksi-transaksi dagang yang menggunakan fasilitas ini. ${ }^{7}$ Terdapat alat yang fungsinya itu untuk menganalisis suatu pesan-pesan yang telah diberikann oleh pengirimnya yang diistilahkan dengan Digital Signature. Transaksi tersebut sama halnya seperti menggunakan suatu kertas yang didalam dokumennya itu terdapat tanda tangan dalam transaksinya, perbedaannya itu penandatanganan itu datanya secara digital. 8

Berdasarkan aturan Pasal 18 juncto Pasal 7 juncto Pasal 11 UU ITE dapat diketahui akta otentik yang dibuatnya oleh pejabat umum yang berwenang, sama kekuatan pembuktiannya dari suatu dokumen elektroniknya dengan digital signature. Aturan

\footnotetext{
${ }^{4}$ Moyambo, E. K. (2019). Tanggung Jawab Notaris Dalam Pembuatan Akta Otentik Berdasarkan Kuasa Lisan Terhadap Masvarakat Umum. Al Oodiri: Turnal Pendidikan, Sosial dan Keagamaan, 17(2). h.117. DOI : https://doi.org/10.1234/al\%20qodiri.v17i2.3416

${ }_{5}$ Prabu, N. M. Z., Purwaningsih, E., \& Yusuf, C. (2020). Problematika Penerapan Cyber Notary Dikaitkan Dengan Undang-Undang Nomor 2 Tahun 2014 tentang Perubahan Atas UndangUndang Nomor 30 Tahun 2004 tentang Jabatan Notaris. Jurnal Surya Kencana Dua: Dinamika Masalah Hukum dan Keadilan, 6(2). h.880. DOI http:/ / dx.doi.org/10.32493/SKD.v6i2.v2019.3995

${ }^{6}$ Harris, F., \& Helena, L. (2017). Notaris Indonesia. Jakarta: PT. Lintas Cetak Djaja. h. 202.

${ }^{7}$ Ariadi, I. W. (2016). Bentuk-Bentuk Digital Signature yang Sah dalam Transaksi Elektronik di Indonesia. Jurnal Magister Hukum Udayana (Udayana Master Law Journal), 5(1), 175-183. h. 179, DOI : https:// doi.org/10.24843/JMHU.2016.v05.i01.p16.

8 Widyaswari, N. M. D. N. (2020). Perlindungan Hukum Bagi Para Pihak Dalam Pembuatan Akta Rups Yang Dilaksanakan Melalui Media Telekonferensi. Vyavahara Duta, 15(1), 62-71. h. 10, DOI : $\underline{\text { http://dx.doi.org/10.25078/vd.v15i1.1440 }}$
} 
tersebut dapat bertentangan dengan aturan Pasal 1 ayat (7) UUJN, yang mengatur bahwa: "akta notaris yang merupakan akta otentik yang dibuat oleh atau dihadapan Notaris menurut bentuk dan tata cara yang ditetapkan dalam Undang-Undang ini."

Berdasarkan pada latar belakang permasalahan tersebut diatas, maka dalam hal ini penulis tertarik untuk melakukan penelitian yang berjudul "Keabsahan Akta Yang Dibuat Oleh Notaris Dengan Digital Siganture". Jadi, permasalahannya yang diangkat dalam karya ilmiah ini yaitu: (1) Bagaimana prosedur pembuatan akta dengan digital signature? Serta (2) Bagaimana keotentikan akta notaris terkait relevansi daripada penggunaan digital signature? Tujuan dari penelitian ini ialah untuk dapat mengetahui prosedur pembuatan akta dengan digital signature serta keotentikan akta notaris terkait relevansi daripada penggunaan digital signature.

Penelitian dengan objek serupa pernah dilakukan oleh Regina Natalie Theixar, pada tahun 2021 dalam Jurnal Acta Comitas yang berjudul "Tanggung Jawab Notaris Dalam Menjaga Keamanan Digitalisasi Akta" membahas mengenai keamanan data para pihak terkait dengan tanggung jawabnya dan juga peran notaris. ${ }^{9}$ Dan penelitian yang dilakukan oleh Ni Kadek Ayu Ena Widiasih, pada tahun 2020 dalam Jurnal Acta Comitas yang berjudul "Kewenangan Notaris dalam Mensertifikasi Transaksi yang Dilkukan Secara Elektronik (Cyber Notary)", membahas mengenai notaris yang memiliki kewenangannya dalam hal sertifikasi. ${ }^{10}$ Dari uraian di atas maka adapun penelitian difokuskan pada yaitu membahas tentang prosedur pembuatan akta dengan digital signature serta keotentikan akta notaris terkait relevansi daripada penggunaan digital signature.

\section{Metode Penelitian}

Metode penelitian dipergunakannya pada penulisan dari karya ilmiah ini yaitu metode penelitian normatif, metode dari penulisan hukum yang meneliti peraturan perundang-undangan tertulis serta bahan-bahan pustaka yang ada, dikaji dengan pendekatan perundang-undangan dan konsep hukum, yaitu menganalisis peraturan perundang-undangan yang terdapat kaitanya dengan permasalahan-permaslahan yang akan dibahas. Penelitian hukum normatif dilakukannya menggunakan cara menelitinya daripada bahan pustakanya atau data sekunder. ${ }^{11}$ Penelitian daripada karya ilmiah ini pula menggunakan suatu pendekatan konseptual (Conceptual approach). Pendekatannya dari sifatnya yuridis-normatif yang mempergunakan dari bahan hukum primer, sekunder, tersier. Teknik pengmpulan bahan hukum yakni ialah studi pustaka dengan suatu analisisnya yang menggunakan suatu metode yang penelitiannya deskriptif-kualitatif.

\section{Hasil Dan Pembahasan}

\subsection{Prosedur dalam Pembuatan Akta Dengan menggunakan Digital Signature}

\footnotetext{
${ }^{9}$ Theixar, R. N., \& Dharmawan, N. K. S. Tanggung Jawab Notaris Dalam Meniaga Keamanan Digitalisasi Akta. Acta Comitas: Jurnal Hukum Kenotariatan,6(01), 1-15. h.1, DOI : https://doi.org/10.24843/AC.2021.v06.i01.p01

${ }_{10}$ Widiasih, N.K. A. E. A Kewenangan Notaris dalam Mensertifikasi Transaksi vang Dilakukan Secara Elektronik (Cyber Notary). Acta Comitas: Jurnal Hukum Kenotariatan, 5(1), 150-160. h.1, DOI : https:/ / doi.org/10.24843/AC.2020.v05.i01.p13

11 Ochtorina, D. A'an Efendi. (2014). Penelitian Hukum (Legal Research). Jakarta: Sinar Grafika. h.19.
} 
Adanya suatu tanda tangan akan memperlihatkan beberapa fungsi-fungsi, yakni:

1. Pembubuhan identitas dari suatu objek hukum maka mencerminkan dari fungsi simbolik dari seseorang.

2. Tanda tangan yang sudah terbaca dan juga diketahui pula dikuncikan dengan keberadaan namanya. Itu mencerminkan fungsi autentifikasi.

3. Tindakan suatu persetujuan terhadap substansi di dalamnya dengan ditanda tangani yang merupakan fungsi persetujuan.

4. Substansi dari informasi mengenai tanda tangan tersebut akan dapat jadi bukti hukum yang merupakan fungsi pembuktian.

Digital signature mempunyai suatu sifat "one signature document" terjadinya perubahan walau hanya sedikit maka digital signature pun berubah dan tak valid lagi. Orisinalitas suatu tanda tangan, terdapat pada suatu dokumen yang telah menyimpan specimen keberadaan tanda tangan tersebut sebelumnya. Tidaklah jauh berbeda dengan suatu tanda tangan yang konvensional yang mana digital signature itu layaknya suatu tanda tangan di atas kertas. Sesuai perkembangan teknologi, Pada suatu digital signature, ada beberapa mode teknologinya yakni:

1. Menggunakan hybrid methods dan juga menggunkaan password;

2. Nantinya Tanda tangan yang akan dipindai dengan cara system elektronik atau juga disebut dengan scanned signature atau pun pengetikan dari suatu nama pada suatu sistem informasi;

3. Menggunakan daripada fitur dari tombol tanda persetujuannya atau juga tanda penerimaannya secara melalui elektronik yang ditunjangnya dengan suatu saluran komunikasinya yang tentunya aman (secured socket layer);

4. Menggunakan daripada suatu tanda dari anggota badan (biometric);

5. Menggunakan daripada yang digital signature berbasiskan dari suatu enkripsi suatu pesan. ${ }^{12}$

Selanjutnya, mengenai digital signature, berdasarkan Pasal 1 angka 12 UU ITE dan Pasal 1 angka 22 Peraturan Pemerintah Republik Indonesia Nomor 71 Tahun 2019 tentang Penyelenggaraan Sistem dan Transaksi Elektronik (selanjutnya disebut PP PSTE), "tanda tangan elektronik didefinisikan sebagai tanda tangan yang terdiri atas informasi elektronik yang dilekatkannya, terasosiasikan atau terkait dengan informasi elektronik lainnya itu yang digunakannya sebagai alat memverifikasi dan autentikasi." Digital Signature memiliki keunikan sikap, yaitu :

1. Dapatlah pula dijadikannya untuk alat bukti di Pengadilan (sempurna), karena keautentikannya;

2. Sah untuk dokumennya itu saja/copynya. tanda tangannya menjadi invalid apabila dokumennya berubah meski hanya satu titik saja;

3. Dapat diperiksa dengan mudah, dengan menggunakan sertifikat elektronik.

Fungsinya suatu tanda tangan ialah untuk memberi ciri dalam akta itu. Definisi penandatanganan ialah memnambahkan nama (tanda tangan penuh) dari si penanda

12 Makarim, E. (2011). Notaris Dan Tanda Tangan Elektronik. Cetakan Pertama. Jakarta: PT.Rajawali Grafindo Persada. h.44. 
tangan. Dianggap belum cukup jika hanya menambah paraf. ${ }^{13}$ Tanda tangan elektronik, yakni meliputi :

a. Digital Signature yang tersertifikasi, tentunya wajib memenuhi persyaratanpersyatan:

1. Keabsahan yang puya kekuatan hukumnya dan pula mempunyai akibat dari hukumnya suatu Digital Signature;

2. Menggunakan suatu sertifikasi elektronik yang juga dibuatnya oleh suatu jasa penyelenggara suatu sertifikasi elektronik di indonesia;

3. Dibuatnya dengan menggunakan suatu perangkat dari pembuat suatu Digital Signature yang telah tersertifikasi.

b. Digital Signature tak tersertifikasi, dibuat dengan tanpa penggunaan jasa penyelenggaraan sertifikasi elektronik di Indonesia.

Digital Signature itu berfungsi guna sebagai suatu alat untuk keautentikan dari informasi elektronik dan verifikasi atas identifikasi dari si penanda tangan. Teknologi informasi dan komunikai tentu telah merubah pola perilaku masyarakatnya dan juga peradaban dari manusia secara global. Selain itu, dunia itu jadi tanpa batas (borderless) yang disebabkan oleh perkembangan pada bidang teknologi informasinya telah mengakibatkan dan juga menyebabkan suatu perubahan-perubahan sosial signifikan berlangsungnya secara cepat. Perkembangan dalam fungsi juga peran notaris pada suatu transaks elektroniknya kemudian dikenal dengan istilahnya yaitu Cyber Notary. ${ }^{14}$ Notaris tentu dituntut untuk mampu dan mengerti dalam hal penggunakan suatu konsep dari cyber notary sehingga terciptanya suatu hal pelayanan jasa, selain efisien dan juga cepat, dan tepat, sehingga nantinya mampu dalam hal mempercepat lajunya pertumbuhan ekonomi. ${ }^{15}$ Persetujuan penandatanganan wajib menggunakannya suatu mekanisme dari afirmasi yang memperlihatkan apa maksud serta tujuan-tujuan penandatangan untuk dapat terikatnya di dalam suatu hal proses transaksi elektronik dari informasi elektronik yang ditandatanganinya nantinya itu dengan digital signature.

Dalam hal perjanjian/kontrak, Pasal 46 PP PSTE, yang mengatur sebagai berikut: "Ayat (1) Transaksi Elektronik itu dapat dilakukan berdasarkan pada Kontrak Elektronik atau bentuk kontraktual yang lainnya sebagai bentuk dari suatu kesepakatan yang dilakukannya oleh para pihakmya. Ayat (2) Kontrak Elektronik tersebut dapat dianggap sah apabila: Terdapatnya kesepakatan para pihak; Dilakukannya oleh subjek hukum yang cakap atau yang juga berwenang untuk mewakili tentunya sesuai dengan ketentuan peraturan perundang-undangan; Terdapat hal tertentu; dan Objek dari transaksi tidak boleh bertentangan dengan peraturan perundang-undangan, kesusilaan, dan ketertiban umum."

Pasal 11 ayat (1) UU ITE dan Pasal 59 ayat (3) PP PSTE yang mengatur bahwa suatu Digital Signature itu mempunyai suatu akibat hukumnya dan suatu kekuatan hukum yang sah itu apabila telah terpenuhinya persyaratan-persyaratan yakni sebagai berikut:

${ }^{13}$ Fakhriah, E. L. (2017). Bukti Elektronik Dalam Sistem Pembuktian Perdata. Bandung: PT.Refika Aditama. h.15.

${ }^{14}$ Nurita, E., \& Ayu, R. (2012). Cyber Notary: Pemahaman Awal dalam Konsep Pemikiran. Bandung: PT.Refika Aditama. h.17.

${ }^{15}$ Ibid., h. 12. 
a. Data-data dari pembuatan Digital Signature hanyalah kepada si Penanda Tangan;

b. Data-data dari pembuatan Digital Signature, prosesnya penandatanganan secara elektronik hanya kuasa si Penanda Tangan;

c. Dapat diketahui semua perubahan-perubahan dari Digital Signature yang telah terjadi setelah waktunya penandatanganan.

d. Dapat diketahuinya semua perubahan-perubahan dari Informasi Elektronik dengan Digital Signature tersebut setelah waktunya penandatanganan;

e. Dapat dipakai cara-cara tertentu untuk mengidentifikasi mengetahui siapa si penanda tangannya;

f. Apabila si penandatangan telah sudah memberikan suatu persetujuan terkait dengan Informasi Elektronik yang bersangkutan, terdapat cara untuk mengetahuinya.

Berdasarkan ketentuan tersebut, suatu digital signature dapattdikatakan sah apbila telah memenuhi ktentuan-ketentuan pada Pasal 11 ayat (1) UU ITE dan Pasal 59 ayat (3) PP PSTE, tanpa melihat adanya profesi ataupun jabatan dari seseorang itu. Dilakukan transaksi elektronik pada proses pembuatan suatu akta oleh notaris yang, yakni:

1. Membuat suatu pasangan kunci public dan kunci privatnya yang dibuat oleh subscriber dengan menemui Certification Authority (CA) yang merupakan lembaga memfasilitasi pihak-pihak dalam transaksi elektronik. Lalu diberikannya bukti identitas dirinya oleh subscriber.

2. Sertifikat siap untuk diterbitkan dan CA memberitahukan subscriber agar dapat memeriksa isi sertifikat tersebut sebelum dipublikasikan. Sertifikat dipublikasikan melalui dengan menggunakan rekam dalam repository atau penyimpanan ataupun disebarnya dengan cara lain.

3. Pembuatan aktanya oleh notaris melalui proses elektronik yang mana prosesnya setara dengan pembutan akta konvensional. Lalu draft akta telah siap, dandilakukan pembacaan isi akta yang nantinya ditandatangani para pihak. Para pihak melihat serta membaca isi draft aktanya pada media elektronik. Terkait adanya penambahan dilakukannya saat penandatangan. Para pihak lalu menyetujui isi dari akta, maka lalu notaris memberikan pihakpihak pada akta dengan digital signature untuk ditandatangani. Dengan kunci publik yakni ialah pasangan dari kunci privat penandatangan, notaris memverifikasi tanda tangan tersebut.

Pada dunia maya atau cyber, dalam melaksanakan proses transaksi elektronik yang berguna agar memberikan suatu kepercayaan-kepercayaan terhadap lawan transaksinya itu untuk mendapat adanya suatu kepastian hukumnya terhadap orang (naturlijk person atau rechtspersoon) maka akan muncullah Penyelenggara Sertifikasi Elektronik. Nantinya dikeluarkan suatu sertifikat yang berguna untuk dipergunakan dalam transaksi. Ketika penerbitan-penerbitan sertifikat itu, terdapat Notaris yang berpartisipasi sebagai registration authority atau otoritas pendaftaran. Identitas dari para pemohon ketika pendaftaran akan diperlukan yang nantinya akan diperlihatkannya ke Notaris jika diterbitkan sertifikatnya. ${ }^{16}$

16 Bahri, S., Yahanan, A., \& Trisaka, A. (2019). Kewenangan Notaris Dalam Mensertifikasi Transaksi Elektronik dalam rangka Cyber Notary. Repertorium: Jurnal Ilmiah Hukum Kenotariatan, 142-157. h. 145 DOI : http://dx.doi.org/10.28946/rpt.v0i0.356 
Akta notaris dalam menciptakan suatu kepastian hukum punya peran penting dikarenakan sifat otentiknya serta dapat digunakan pula sebagai suatu alat dalam hal ini berhubungan pembuktian jika ada masalah dengan aktanya tersebut. ${ }^{17}$ Kepastian hukum adalah ciri-ciri dari spesifikasi hukum. Hukum itu tanpa tiada suatu nilai-nilai kepastian yang maka tentu berdampak pada hilangnya dalam maknanya karena tidaklah dapat untuk dijadikan sebuah pedoman-pedoman dalam kehidupan masyarakat. 18 Seiring dengan meningkatnya suatu hubungan-hubungan bisnis semakin meningkat pula kebutuhan akan akta otentik. Akta notaris ada 2 jenis yakni yang pertama itu ialah akta partij (dimana pihak-pihaknya itu langsung menghadap dengan notaris dan juga menandatangani langsung aktanya) dan akta relaas (dimana notarislah disini yang menandatangani aktanya yang isinya itu menjelaskan adanya suatu kejadian), akta relaas dimungkinkan dengan penggunaan tanda tangan elektronik. Contohnya adalah terdapat pada Rapat Umum Pemegang Saham (RUPS) yang telah diadakannya melalui cara prosesnya menggunakan dari penerapannya video conference. Yang mana hal tersebut tentu dimungkinkan dikarenakan notaris dapat secara langsung dapat terlibat berkontribusi dan tentunya juga hadir dalam menyaksikan proses RUPS tersebut.

\subsection{Relevansi dari Penerapan Tanda Tangan Elektronik terhadap Suatu Keotentikan Akta Notaris}

Kekuatan hukum serta akibat hukum digital signature disamakan dengan suatu tanda tangan yang manual sebagaimana yang terdapat pada ketentuan penjelasan Pasal 11 UU ITE. Dengan menandatanganinya, dan menunjukkannya terdapat persetujuan penandatanganan sekaligus dari isi yang telah tercantum dalam tulisannya tersebut dapat menjamin kebenarannya. Maka, untuk dapat mempunyai suatu akibat hukumnya yang secara sah dan juga suatu kekuatan hukum maka dari itu digital signature wajib memenuhi suatu persyaratan-persyaratan dalam memnuhi persyaratan Pasal 11 ayat (1) UU ITE, Selanjutnya dalam Pasal 60 PP PSTE mengatur bahwa : “Tanda Tangan Elektronik yang berfungsinya itu sebagai alat untuk autentifikasi dan juga verifikasi atas Identitas dari Penanda Tangan; dan Keutuhan dan juga Keautentikan Informasi Elektronik."

Terkait penanda tangan atas kepastian data pada digital signature diatur pada Pasal 61 PP PSTE, yang mengatur bahwa:

1. Data-data yang dimiliki pembuat tanda tangan yang memiliki keunikan sehingga merujuknya pada penanda tangan untuk mengidentifikasinya.

2. Data-data yang diperoleh itu dibuat oleh penyelengara digital signature.

3. Data dari Pembuatan Tanda Tangan Elektronik, wajib untuk memenuhi ketentuan-ketentuan berikut:

a. Apabila pembuatannya itu menggunakan kode kriptografi, datanya harus tak mudah untuk diketahuinya dari data yang terdapat verifikas digital signature lewat suatu kurun waktu, suatu perhiungan tertentu.

17 Afriana, A. (2020). Kedudukan Dan Tanggung Jawab Notaris Sebagai Pihak Dalam Penyelesaian Sengketa Perdata Di Indonesia Terkait Akta Yang Dibuatnya. Iurnal Poros Hukum Padjadjaran, 1(2), 246-261. h. 249, DOI : https://doi.org/10.23920/iphp.v1i2.250

18 Rizkianti, W. (2017). Akta Otentik Rapat Umum Pemegang Saham (Rups) melalui Media Telekonferensi (Mekanisme Pembuatan dan Kekuatan Pembuktiannya). Jurnal Yuridis, 3(1), 83-98, h.87. DOI : http://dx.doi.org/10.35586/.v3i1.172 
b. Data pembuatannya itu penguasaan berada pada si Penanda Tangan dan tersimpan di media elektronik.

c. Si Penanda Tangan wajib untuk menyimpan data yang telah terkait dengan melalui sistem terpercaya yang dimiliki Penyelenggara yang dapat mendeteksi apabila terdapat adanya suatu perubahan dan juga memenuhinya persyaratan, yaitu:

1. Untuk dapat memasukkan suatu data baru, mengubahnya, menukarnya, dan atau mengganti datanya, hanyalah orang-orang yang memiliki wewenang;

2. Dapatlah diperiksakan keautentikan Informasi dari identitas dari Penanda Tangan; dan

3. Dapat dideteksi ataupun diketahui oleh penyelenggara mengenai adanya Perubahan dari teknis lainnya yang telah melanggar ketentuan dari persyaratan-persyaratan dari keamanan itu.

d. Apabila dari data itu dibuat oleh Penyelenggara maka dari itu kesemua proses pembuatan dari data dijamin dari segi keamanan dan juga kerahasiaannya oleh Penyelenggara.

4. Berkewajiban untuk bertanggung jawab si penanda tangan dan juga menjaga kerahasiaan data.

Merujuk kepada ketentuan aturan Pasal 5 ayat (4) UU ITE, diketahui bahwa tidak termasuk ke dalam dokumen elektronik, suatu dokumen yang dibuat dalam bentuk akta notariil. Sebaliknya, tidak untuk dapat dijadikan sebagai akta otentik suatu informasi/dokumen elektronik itu. Notaris yang mempunyai suatu wewenang untuk membuatkan suatu akta otentik pada hal ini hanya untuk dalam hal waarmeking atau melegalisasi digital signature. Pasal 5 ayat (3) UU ITE, yang mengatur mengenai "suatu Informasi Elektronik dan/atau dokumen elektronik sebagaimana dimaksud pada ayat (1) tidak berlaku untuk:" "a.Surat yang wajib dibuat dalam bentuk tertulis. b.Surat dan beserta dokumen-dokumennya itu wajib untuk dibuatkan dalam bentuk akta notariil ataupun akta yang dibuatkan oleh pejabat pembuat akta."

Mengingat ketentuan aturan pada Pasal 16 ayat (1) UUJN huruf c, dan m, mengatur bahwa: “(1) Melekatkannya surat dan juga dokumen dan serta sidik jari dari para penghadap pada minuta aktanya. (2) Membacakannya akta itu di hadapan para penghadap dengan juga dihadiri oleh paling sedikitnya itu 2 (dua) orang saksi-saksi, ataupun 4 (empat) orang saksi khusus untuk pembuatannya akta wasiat di bawah tangan itu, dan ditandatangani itu pada saat itu juga oleh para penghadap, saksi, dan notarisnya."

Dokumen-dokumen elektronik yang mempunyai suatu kedudukan pembuktian dikarenakan suatu dokumen elektronik tidak dapat berdiri sendiri sehingga wajib untuk dilengkapi dengan alat bukti lain. Pertimbangan-pertimbangan dari hakim yang merupakan nilai dari kekuatan dalam hal pembuktiannya, sifat daripada kekuatan dari pembuktianya itu ialah bebas. Sebagai alat bukti, maka dimana dalam surat atau aktanya yang terdapat digital signature tersebut, di Indonesia yang kekuatannya dapat bisa diuraikan jadi akta otentik atau akta dibawah tangan dan masuk ke dalam alat bukti surat. Akta otentik apabila digital signaturenya telah terverifikasi. Masuk ke dalam Akta dibawah tangan jika digital signaturenya belum terverifikasi. 


\section{Kesimpulan}

Digital Signature dilakukan pada suatu proses transaksi elektronik, ialah suatu perbuatan hukum prosesnya itu dengan mempergunakan computer, jaringan computer, dan juga media elektronik lainnya. Pembuatan suatu akta oleh notaris melalui proses elektronik itu hampir mirip sama prosesnya dengan proses pembuatannya akta konvensional. Lalu jika draft akta sudah siap, dilakukanlah pembacaan mengenai isi akta yang akan di tandatangani kepada para pihak. Lalu para pihak membaca dan melihat draft akta melalui media elektronik. Jika terdapat penambahan ataupun koreksi dari draft akta, yang dilakukan saat penandatangan. Para pihak menyetujui isi dari akta, maka notaris akan mempersilahkan pihak-pihak untuk menandatanganinya aktanya dengan digital signature. Lalu notaris memverifikasi tanda tangan tersebut. Suatu digital signature dikatakan sah jika telah memenuhi ketentuan-ketentuan sebagaimana yang telah diatur padaketntuan Pasal 11 ayat (1) UU ITE dan Pasal 59 ayat (3) PP PSTE. Sebagai alat bukti, maka dimana dalam surat atau aktanya yang terdapat digital signature tersebut, di Indonesia yang kekuatannya dapat bisa diuraikan jadi akta otentik atau akta dibawah tangan dan masuk ke dalam alat bukti surat. Akta otentik apabila digital signaturnya telah terverifikasi. Sebaliknya akan masuk ke dalam Akta dibawah tangan jika digital signaturenya belum terverifikasi.

\section{Daftar Pustaka}

\section{Buku:}

Fakhriah, E. L. (2017). Bukti Elektronik Dalam Sistem Pembuktian Perdata. Bandung: PT.Refika Aditama.

Harris, F., \& Helena, L. (2017). Notaris Indonesia. Jakarta: PT. Lintas Cetak Djaja.

Makarim, E. (2011). Notaris Dan Tanda Tangan Elektronik. Cetakan Pertama. Jakarta: PT.Rajawali Grafindo Persada.

Nurita, E., \& Ayu, R. (2012). Cyber Notary: Pemahaman Awal dalam Konsep Pemikiran. Bandung: PT.Refika Aditama.

Ochtorina, D. A'an Efendi. (2014). Penelitian Hukum (Legal Research). Jakarta: Sinar Grafika.

\section{Jurnal:}

Abdullah, N. (2017). Kedudukan Dan Kewenangan Notaris Dalam Membuat Akta Otentik. Jurnal Akta, 4(4), 655-664. DOI : http://dx.doi.org/10.30659/akta.v4i4.2508

Afriana, A. (2020). Kedudukan Dan Tanggung Jawab Notaris Sebagai Pihak Dalam Penyelesaian Sengketa Perdata Di Indonesia Terkait Akta Yang 
Dibuatnya. Jurnal Poros Hukum Padjadjaran, 1(2), 246-261. DOI : https://doi.org/10.23920/jphp.v1i2.250

Alwajdi, M. F. (2020). Urgensi Pengaturan Cyber Notary Dalam Mendukung Kemudahan Berusaha Di Indonesia. Jurnal Rechts Vinding: Media Pembinaan Hukum Nasional, 9(2), 257.2 DOI: http://dx.doi.org/10.33331/rechtsvinding.v9i2.422

Ariadi, I. W. (2016). Bentuk-Bentuk Digital Signature yang Sah dalam Transaksi Elektronik di Indonesia. Jurnal Magister Hukum Udayana (Udayana Master Law Journal), 5(1), 175-183. DOI : https://doi.org/10.24843/JMHU.2016.v05.i01.p16.

Bahri, S., Yahanan, A., \& Trisaka, A. (2019). Kewenangan Notaris Dalam Mensertifikasi Transaksi Elektronik dalam rangka Cyber Notary. Repertorium: Jumal Ilmiah Hukum Kenotariatan, 142-157. DOI : http://dx.doi.org/10.28946/rpt.v0i0.356

Moyambo, E. K. (2019). Tanggung Jawab Notaris Dalam Pembuatan Akta Otentik Berdasarkan Kuasa Lisan Terhadap Masyarakat Umum. Al Qodiri: Jumal Pendidikan, Sosial dan Keagamaan, 17(2). DOI : https://doi.org/10.1234/al\%20qodiri.v17i2.3416

Prabu, N. M. Z., Purwaningsih, E., \& Yusuf, C. (2020). Problematika Penerapan Cyber Notary Dikaitkan Dengan Undang-Undang Nomor 2 Tahun 2014 tentang Perubahan Atas Undang-Undang Nomor 30 Tahun 2004 tentang Jabatan Notaris. Jurnal Surya Kencana Dua: Dinamika Masalah Hukum dan Keadilan, 6(2). DOI : http://dx.doi.org/10.32493/SKD.v6i2.y2019.3995

Putri, C. C., \& Budiono, A. R. (2019). Konseptualisasi Dan Peluang Cyber Notary Dalam Hukum. Jurnal Ilmiah Pendidikan Pancasila dan Kewarganegaraan, 4(1), 2936. DOI: http://dx.doi.org/10.17977/um019v4i1p29-36

Rizkianti, W. (2017). Akta Otentik Rapat Umum Pemegang Saham (Rups) melalui Media Telekonferensi (Mekanisme Pembuatan dan Kekuatan Pembuktiannya). Jurnal Yuridis, 3(1), 83-98. DOI : http://dx.doi.org/10.35586/.v3i1.172

Theixar, R. N., \& Dharmawan, N. K. S. Tanggung Jawab Notaris Dalam Menjaga Keamanan Digitalisasi Akta. Acta Comitas: Jurnal Hukum Kenotariatan, 6(01), 115. DOI : https://doi.org/10.24843/AC.2021.v06.i01.p01

Widiasih, N. K. A. E. A Kewenangan Notaris dalam Mensertifikasi Transaksi yang Dilakukan Secara Elektronik (Cyber Notary). Acta Comitas: Jurnal Hukum Kenotariatan, 5(1), 150-160. DOI : https://doi.org/10.24843/AC.2020.v05.i01.p13

Widyaswari, N. M. D. N. (2020). Perlindungan Hukum Bagi Para Pihak Dalam Pembuatan Akta Rups Yang Dilaksanakan Melalui Media Telekonferensi. Vyavahara Duta, 15(1), 62-71. DOI : http://dx.doi.org/10.25078/vd.v15i1.1440 


\section{Peraturan Perundang-undangan:}

Undang-Undang Dasar Negara Republik Indonesia Tahun 1945.

Kitab Undang-Undang Hukum Perdata, diterjemahkan oleh R. Subekti dan R. Tjitrosudibio, 2004, cet. XXXIV, Pradnya Paramitha, Jakarta.

Undang-Undang Nomor 2 Tahun 2014 tentang Perubahan Atas Undang-Undang Nomor 30 Tahun 2004 tentang Jabatan Notaris (Lembaran Negara Republik Indonesia Tahun 2014 Nomor 3, Tambahan Lembaran Negara Republik Indonesia Nomor 5491).

Undang-Undang Nomor 19 Tahun 2016 tentang Perubahan Atas Undang-Undang Nomor 11 Tahun 2008 tentang Informasi dan Transaksi Elektronik (Lembaran Negara Tahun 2016 Nomor 251, Tambahan Lembaran Negara Republik Indonesia Nomor 5952).

Peraturan Pemerintah Nomor 71 Tahun 2019 tentang Penyelenggaraan Sistem dan Transaksi Elektronik (Lembaran Negara Tahun 2019 Nomor 185, Tambahan Lembaran Negara Republik Indonesia Nomor 6400). 